\title{
ORGANOGÊNESE A PARTIR DE SEGMENTOS FOLIARES E INTERNODAIS DE VIDEIRA CV. MERLOT
}

\author{
Organogenesis from leaf segments and internodes of grapevine cv. Merlot
}

\author{
Dayse Cristina de Carvalho', André Luís Lopes da Silva², \\ Guilherme Nakao Tanno ${ }^{2}$, Marivel Purcino ${ }^{2}$, Luiz Antonio Biasi ${ }^{3}$
}

\begin{abstract}
RESUMO
Objetivou-se, neste trabalho, estudar a indução da organogênese em segmentos foliares e internódios de videira cv. Merlot, utilizando diferentes tipos e concentrações de citocininas. O meio de cultura usado foi o MS com redução da metade dos sais e vitaminas, suplementado com $1 \mu \mathrm{M}$ de ácido naftalenoacético (ANA). Os tratamentos consistiram das concentrações de 2,5; 5,0 ou $10 \mu \mathrm{M}$ de 6-benzilaminopurina (BAP) ou 1-fenil-3-(1,2,3,-tiadiazol-5-il) uréia (TDZ). Foram avaliados o porcentual de formação de gemas, calos, oxidação e raízes, além do número de raízes e gemas. Aos 60 dias de cultivo in vitro foi observado que concentrações de 2,5-10 $\mu \mathrm{M}$ de BAP e TDZ permitem que segmentos foliares oxidem e não induzam à oxidação nos internódios. O nível de $5 \mu \mathrm{M}$ de TDZ favore o maior porcentual de formação de gemas em internódios e segmentos foliares não apresentam capacidade para formar gemas nos níveis de 2,5-10 $\mu \mathrm{M}$ de BAP ou TDZ. O uso de BAP nas concentrações de 2,5 e $5 \mu \mathrm{M}$ favorece altos porcentuais de enraizamento em internódios. O uso de TDZ no nível de $2,5 \mu \mathrm{M}$ promove elevada taxa de formação de calos em internódios. Os internódios apresentaram maior capacidade organogênica do que os segmentos foliares.
\end{abstract}

Termos para indexação: Vitis vinifera, enraizamento in vitro, morfogênese in vitro, oxidação fenólica, citocinina.

\section{ABSTRACT}

The objective of this work was study the induction of organogenesis on leaf segments and internodes of grapevine cv. Merlot using different types and concentrations of cytokinins. MS half strength culture medium supplemented with $1 \mu \mathrm{M}$ naftalenoacetic acid (NAA) was used. The treatments consisted of the concentrations of 2.5; 5.0 or $10 \mu \mathrm{M}$ 6-benzilaminopurine (BAP) or thydiazuron (TDZ). The percentage of buds, callus, oxidation and roots as well as the number of roots and buds were evaluated. After 60 days of in vitro culture it was observed that the concentrations of 2.5-10 $\mu \mathrm{M}$ BAP or TDZ oxidize leaf segments and do not induce oxidation in the internodes. The level of $5 \mu \mathrm{M} \mathrm{TDZ}$ promote the largest formation of buds from internodes and leaf segments do not have capacity to form buds at the levels of 2,5-10 $\mu \mathrm{M}$ BAP or TDZ. The use of BAP at the concentrations of 2.5 and $5 \mu \mathrm{M}$ promote high rooting percentage of internodes. TDZ at the level of $2.5 \mu \mathrm{M}$ promotes high rate of callus formation in internodes. Internodes presented larger organogenic capacity than leaf segments.

Index terms: Vitis vinifera, in vitro rooting, in vitro morphogenesis, phenolic oxidation, cytokinin.

\section{(Recebido em 17 de agosto de 2009 e aprovado em 22 de março de 2010)}

\section{INTRODUÇÃo}

A viticultura brasileira ocupa uma área de 73,9 mil hectares, com uma produção de 1,2 milhões de toneladas, contribuindo com $1,8 \%$ de toda a uva consumida no mundo (Instituto Brasileiro de Geografia e Estatística - IBGE, 2007). A atividade tem se expandido notadamente em regiões não tradicionais do país, como Mato Grosso do Sul, Goiás, Espírito Santo e Ceará principalmente em pequenas propriedades (Mello, 2007). Entretanto, apesar da atividade ter demonstrado crescimento nos últimos anos, a maioria das cultivares copa e porta-enxerto, são muito suscetíveis ao ataque de pragas e doenças, sendo decorrentes desse fato a redução da qualidade, da produtividade dos pomares e a consequente elevação dos custos de produção (Sônego et al., 2005).

O desenvolvimento de protocolos de micropropagação, embriogênese somática e cultura de células em suspensão representam a possibilidade de superação dos entraves encontrados no atual sistema de propagação de videiras, além de fornecerem suporte para o melhoramento da espécie através de técnicas biotecnológicas como a hibridação somática e a transformação genética, as quais são dependentes de protocolos eficientes de regeneração de plantas. A cultura de tecidos de videiras foi idealizado inicialmente como um modo prático de resolver problemas sanitários, como a obtenção de clones livre de vírus (Bajaj, 1992).

\footnotetext{
${ }^{1}$ Universidade Federal do Paraná/UFPR - Laboratório de Micropropagação de Plantas - 80001970 - Curitiba, PR - daysecristy@yahoo.com.br 2Universidade Federal do Paraná/UFPR - Laboratório de Micropropagação de Plantas - Curitiba, PR

3Universidade Federal do Paraná/UFPR - Departamento de Fitotecnia e Fitossanitarismo - Curitiba, PR
} 
Durante a década de sessenta foram iniciados os trabalhos com cultura de tecidos, visando determinar a composição do meio de cultura para o estabelecimento da planta. Desde então, diversas publicações têm relatado diferentes aplicações da micropropagação de videira, tais como: cultura de embriões (Bouquet \& Davies, 1989), cultura de calos (Stamp et al., 1990), cultura de protoplastos (Brown \& Coombe, 1984), embriogênese somática (Zlenko et al., 2005), transformação genética (Vidal et al., 2006) e produção de sementes sintéticas (Das et al., 2006).

A regeneração de videiras via organogênese tem sido descrita a partir de diferentes explantes, tais como folhas peciolares (Stamp et al., 1990), ápices caulinares (Goussard, 1981) e meristemas (Mezzetti et al., 2002). Entretanto, apesar de todo esse conhecimento já produzido, as cultivares de videira apresentam respostas variadas no cultivo in vitro. Objetivou-se, neste trabalho, estudar a indução da organogênese a partir de segmentos foliares e internódios de Vitis vinifera cv. Merlot, utilizando diferentes tipos e concentrações de citocininas.

\section{MATERIAL E MÉTODOS}

Plantas de Vitis vinifera L. cv. Merlot foram estabelecidas in vitro a partir de segmentos nodais de estacas brotadas em condições de sala de crescimento e subcultivadas em intervalos de 30 dias em meio MS (Murashige \& Skoog, 1962) com metade da concentração de sais (Goussard, 1981). Essas plantas estabelecidas in vitro foram às doadoras dos explantes, que foram segmentos foliares e segmentos internodais (internódios).

Os segmentos foliares consistiram de quadrados de $25 \mathrm{~mm}^{2}$ de área do mesófilo foliar sem a nervura central, os quais foram colocados com a face abaxial em contato com o meio de cultivo. Os segmentos internodais (desprovidos de gemas) foram excisados com $10 \mathrm{~mm}$ de comprimento e colocados horizontalmente no meio de cultivo. O meio basal foi o MS com metade da concentração de sais e vitaminas, com $30 \mathrm{~g} \mathrm{~L}^{-1}$ de sacarose e $6 \mathrm{~g} \mathrm{~L}^{-1} \mathrm{de}$ ágar e suplementado com $1 \mu \mathrm{M}$ de ácido naftalenoacético (ANA), o pH foi ajustado para 5,8 antes da autoclavagem. Os explantes foram segmentos foliares e internodais, as citocininas foram 6-benzilaminopurina (BAP) e 1-fenil-3(1,2,3,-tiadiazol-5-il) uréia (TDZ) nas concentrações de 2,5; 5,0 ou $10 \mu \mathrm{M}$. As placas de petri contendo $20 \mathrm{~mL}$ de meio foram mantidas no escuro durante os primeiros 20 dias, sendo transferidas após esse período para condições de luminosidade. Os explantes permaneceram em sala de crescimento com temperatura de $25 \pm 2^{\circ} \mathrm{C}$ e fotoperíodo de $16 \mathrm{~h}$, sob intensidade luminosa de $30 \mu \mathrm{M} \mathrm{m}^{-2} \mathrm{~s}^{-1}$ obtida de lâmpadas fluorescentes brancas.
O delineamento usado foi inteiramente casualisado num esquema trifatorial $(2 \times 2 \times 3)$, sendo dois tipos de explantes (Segmento foliar e internódio), dois tipos de citocininas (BAP e TDZ) e três concentrações $(2,5 ; 5,0$ e $10,0 \mu \mathrm{M}$ ). Foram utilizadas quatro repetições com 20 explantes por parcela. Foram avaliados os porcentuais de oxidação, formação de calo, indução de raízes e formação de gemas, o número de raízes e gemas por explante aos 60 dias de cultivo in vitro. Os dados foram submetidos à análise de variância e ao teste de comparação múltipla de médias de Tukey, ao nível de 5\% de probabilidade de erro. Os dados oriundos de porcentagem foram transformados para arcoseno $\sqrt{x / 100}$ e os de contagem para $\sqrt{x+1}$. Os dados foram processados com auxílio do programa computacional GENES (Cruz, 2001).

\section{RESULTADOS E DISCUSSÃO}

A interação entre o tipo de explante e o tipo de citocinina foi significativa $(\mathrm{P}<0,01)$ para a porcentagem de enraizamento e gemas, e para o número de raízes e gemas. O tipo de explante e a concentração de citocinina apresentaram interação significativa $(\mathrm{P}<0,01)$, para $\mathrm{o}$ número e porcentual de raízes e $(\mathrm{P}<0,05)$, para o porcentual de oxidação dos explantes. A interação entre o tipo de citocinina e a concentração usada foi significativa $(\mathrm{P}<0,01)$ para o porcentual de oxidação, de gemas e raízes e para o número de raízes, e significativa $(\mathrm{P}<0,05)$ para o porcentual de calos e o número de gemas. A interação tripla não foi significativa para o porcentual de calos, entretanto foi significativa $(\mathrm{P}<0,01)$ para o número de raízes e para o porcentual de oxidação, raízes e gemas, e significativa $(\mathrm{P}<0,05)$ para o número de gemas (Tabela 1$)$.

O tipo de explante apresentou diferenças significativas com relação ao porcentual de oxidação, os internódios não oxidaram, porém os segmentos foliares apresentaram uma média geral de $37,2 \%$ de oxidação. As concentrações de BAP não diferiram significativamente para os segmentos foliares, ao invés das concentrações de TDZ que promoveram diferentes porcentuais de oxidação nos segmentos foliares atingindo o maior porcentual, 88,3 no nível de $5 \mu \mathrm{M}$ (Tabela 2).

Os segmentos foliares não formaram gemas em nenhuma das concentrações de TDZ e BAP, porém os internódios formaram gemas nas concentrações de $10 \mu \mathrm{M}$ de BAP e 2,5; 5,0 e 10,0 $\mu \mathrm{M}$ de TDZ. A melhor concentração de TDZ foi 5,0 $\mu \mathrm{M}$, atingindo $21,6 \%$ de explantes com gemas, porém a concentração de $2,5 \mu \mathrm{M}$ apresentou o maior número de gemas por explante (Figura 1-a e b). O BAP apresentou baixa porcentagem e número de gemas por explante, $6,6 \%$ e 0,1 , respectivamente (Tabela 2). 
Tabela 1 - Quadrados médios oriundos da análise de variância. Calos formados $(\mathrm{C} \%)$, Oxidação dos explantes $(\mathrm{O} \%)$, Explantes enraizados (E \%), Formação de gemas (G \%), Número de raízes (NR), Número de gemas (NG) em internódios e segmentos foliares de videira cv. Merlot, aos 60 dias de cultivo in vitro.

\begin{tabular}{|c|c|c|c|c|c|c|c|}
\hline \multirow[b]{2}{*}{ F.V. } & \multicolumn{7}{|c|}{ Quadrados médios } \\
\hline & GL & $\mathrm{C} \%$ & $\mathrm{O} \%$ & $\mathrm{E} \%$ & $\mathrm{G} \%$ & NR & NG \\
\hline $\mathrm{A}^{(1)}$ & 1 & $11114,2^{*}$ & $15023,1^{*}$ & $6112,7^{*}$ & $1341,5^{*}$ & 0,951 * & 0,088 * \\
\hline $\mathrm{B}^{(2)}$ & 1 & $695,1^{\mathrm{ns}}$ & $95,1^{\mathrm{ns}}$ & $9512,9^{*}$ & $483,9^{*}$ & $1,564 *$ & 0,054 * \\
\hline $\mathrm{C}^{(3)}$ & 2 & $4552,5^{*}$ & $736,9^{* *}$ & $2246,1^{*}$ & $28,0^{\mathrm{ns}}$ & 0,429 * & $0,011^{\mathrm{ns}}$ \\
\hline$A \times B$ & 1 & $347,8^{\mathrm{ns}}$ & $95,1^{\mathrm{ns}}$ & $5229,1^{*}$ & $483,9^{*}$ & $0,932^{*}$ & 0,054 * \\
\hline $\mathrm{A} \times \mathrm{C}$ & 2 & $3174,8^{*}$ & $736,9^{* *}$ & $1558,5^{*}$ & $28,0^{\mathrm{ns}}$ & 0,232 * & $0,011^{\mathrm{ns}}$ \\
\hline $\mathrm{B} \times \mathrm{C}$ & 2 & $668,1^{* *}$ & $1064,4^{*}$ & $2033,4^{*}$ & 328,0 * & 0,426 * & $0,022^{* *}$ \\
\hline$A \times B \times C$ & 2 & $215,6^{\mathrm{ns}}$ & $1064,4^{*}$ & $1197,6^{*}$ & 328,0 * & $0,227^{*}$ & $0,022^{* *}$ \\
\hline Resíduo & 36 & 170,0 & 153,2 & 68,6 & 15,1 & 0,007 & 0,004 \\
\hline $\mathrm{CV}(\%)$ & & 52,7 & 69,9 & 55,4 & 73,7 & 7,3 & 6,4 \\
\hline
\end{tabular}

${ }^{(1)}$ Tipo de explante, ${ }^{(2)}$ Tipo de citocinina, ${ }^{(3)}$ Concentrações das citocininas, ${ }^{*}$ significativo ao nível de $1 \%$ de probabilidade de erro pelo teste $\mathrm{F},{ }^{* *}$ significativo ao nível de $5 \%$ de probabilidade de erro pelo teste $\mathrm{F}$, ${ }^{\text {ns }}$ Não significativo.

Tabela 2 - Porcentual de oxidação, porcentual de explantes que formaram gemas e número de gemas por explante em videira cv. Merlot, aos 60 dias de cultivo in vitro.

\begin{tabular}{|c|c|c|c|c|}
\hline \multicolumn{5}{|c|}{ Oxidação (\%) } \\
\hline \multirow[t]{2}{*}{$\mu \mathrm{M}$} & \multicolumn{2}{|c|}{ BAP } & \multicolumn{2}{|c|}{ TDZ } \\
\hline & Seg. foliares & Internódios & Seg. foliares & Internódios \\
\hline 2,5 & $36,6 \mathrm{aA}^{(1)}$ & $0 \mathrm{aB}$ & $16,6 \mathrm{bB}$ & $0 \mathrm{aB}$ \\
\hline 5,0 & $30,0 \mathrm{aB}$ & $0 \mathrm{aC}$ & $88,3 \mathrm{aA}$ & $0 \mathrm{aC}$ \\
\hline 10,0 & $33,3 \mathrm{aA}$ & $0 \mathrm{aB}$ & $18,3 \mathrm{bAB}$ & $0 \mathrm{aB}$ \\
\hline \multicolumn{5}{|c|}{ Explantes com gemas $(\%)$} \\
\hline$\mu \mathrm{M}$ & \multicolumn{2}{|c|}{ BAP } & \multicolumn{2}{|c|}{ TDZ } \\
\hline & Seg. foliares & Internódios & Seg. foliares & Internódios \\
\hline 2,5 & $0 \mathrm{aB}$ & $0 \mathrm{aB}$ & $0 \mathrm{aB}$ & $10,0 \mathrm{bA}$ \\
\hline 5,0 & $0 \mathrm{aB}$ & $0 \mathrm{aB}$ & $0 \mathrm{aB}$ & $21,6 \mathrm{aA}$ \\
\hline 10,0 & $0 \mathrm{aA}$ & $6,6 \mathrm{aA}$ & $0 \mathrm{aA}$ & $1,6 \mathrm{cA}$ \\
\hline \multicolumn{5}{|c|}{ Número de gemas por explante } \\
\hline$\mu \mathrm{M}$ & \multicolumn{2}{|c|}{ BAP } & \multicolumn{2}{|c|}{ TDZ } \\
\hline & Seg. foliares & Internódios & Seg. foliares & Internódios \\
\hline 2,5 & $0 \mathrm{aB}$ & $0 \mathrm{aB}$ & $0 \mathrm{aB}$ & $0,7 \mathrm{aA}$ \\
\hline 5,0 & $0 \mathrm{aB}$ & $0 \mathrm{aB}$ & $0 \mathrm{aB}$ & $0,25 \mathrm{bA}$ \\
\hline 10,0 & $0 \mathrm{aA}$ & $0,1 \mathrm{aA}$ & $0 \mathrm{aA}$ & $0,1 \mathrm{cA}$ \\
\hline
\end{tabular}

${ }^{(1)}$ Tratamentos seguidos por letras idênticas minúsculas nas colunas e maiúsculas nas linhas não diferem entre si pelo teste de Tukey, ao nível de 5\% de probabilidade de erro.

Internódios apresentaram porcentual de enraizamento significativamente superiores aos segmentos foliares, em meio de cultura com 2,5 e $5 \mu \mathrm{M}$ de BAP. Os segmentos foliares enraizaram somente na presença de $2,5 \mu \mathrm{M}$ de BAP, atingindo 18,3\% de enraizamento. O BAP nas concentrações de 2,5 e $5 \mu \mathrm{M}$ foi superior ao TDZ no enraizamento de internódios. O maior porcentual foi $95 \%$ na concentração de $5 \mu \mathrm{M}$, seguido de $80 \% \operatorname{com} 2,5 \mu \mathrm{M}$ e 
apenas $1,6 \%$ com $10 \mu \mathrm{M}$. O TDZ induziu o enraizamento em internódios apenas na concentração de $5 \mu \mathrm{M}$, com percentual de 1,6\% (Tabela 3). O melhor resultado com relação ao número de raízes foi 3,2 raízes por explante com 2,5 $\mu \mathrm{M}$ de BAP nos internódios (Figura 1-d), seguido da concentração de $5 \mu \mathrm{M}$ de BAP que apresentou 2,5 raízes por explante (Tabela 3 ).

A formação de calos foi influenciada significativamente pelo tipo de explante usado. Internódios são mais responsivos à formação de calo, alcançando em média $47,4 \%$, por outro lado, os segmentos foliares apresentam uma média geral de apenas 7,2\%. O tipo de citocinina não apresentou diferenças estatísticas, resultando numa formação de calos de $21,9 \%$ com BAP e 32,7\% com TDZ. O melhor resultado para a formação de calos foi $90 \%$ obtido com $2,5 \mu \mathrm{M}$ de TDZ em internódios
(Tabela 3 e Figura 1-c). A indução de calos e gemas nos internódios ocorreu nas duas extremidades do explante.

\section{RESULTADOS E DISCUSSÃO}

A ocorrência da oxidação em explantes de plantas lenhosas é um problema comum, e também afeta a videira (Jaskani et al., 2008). Entretanto, a ocorrência e a intensidade da oxidação em explantes de videira parece ser uma característica inerente ao tipo de explante usado. Meristemas contendo dois ou mais primórdios foliares da cultivar 'A Dona' apresentaram reduzidos porcentuais de oxidação, variando de 4 a $6 \%$ em presença das concentrações de 2 a $10 \mu \mathrm{M}$ de BAP (Passos et al., 1985), por outro lado, segmentos nodais do porta-enxerto de videira 'Jales' após 40 dias de cultivo in vitro nos níveis
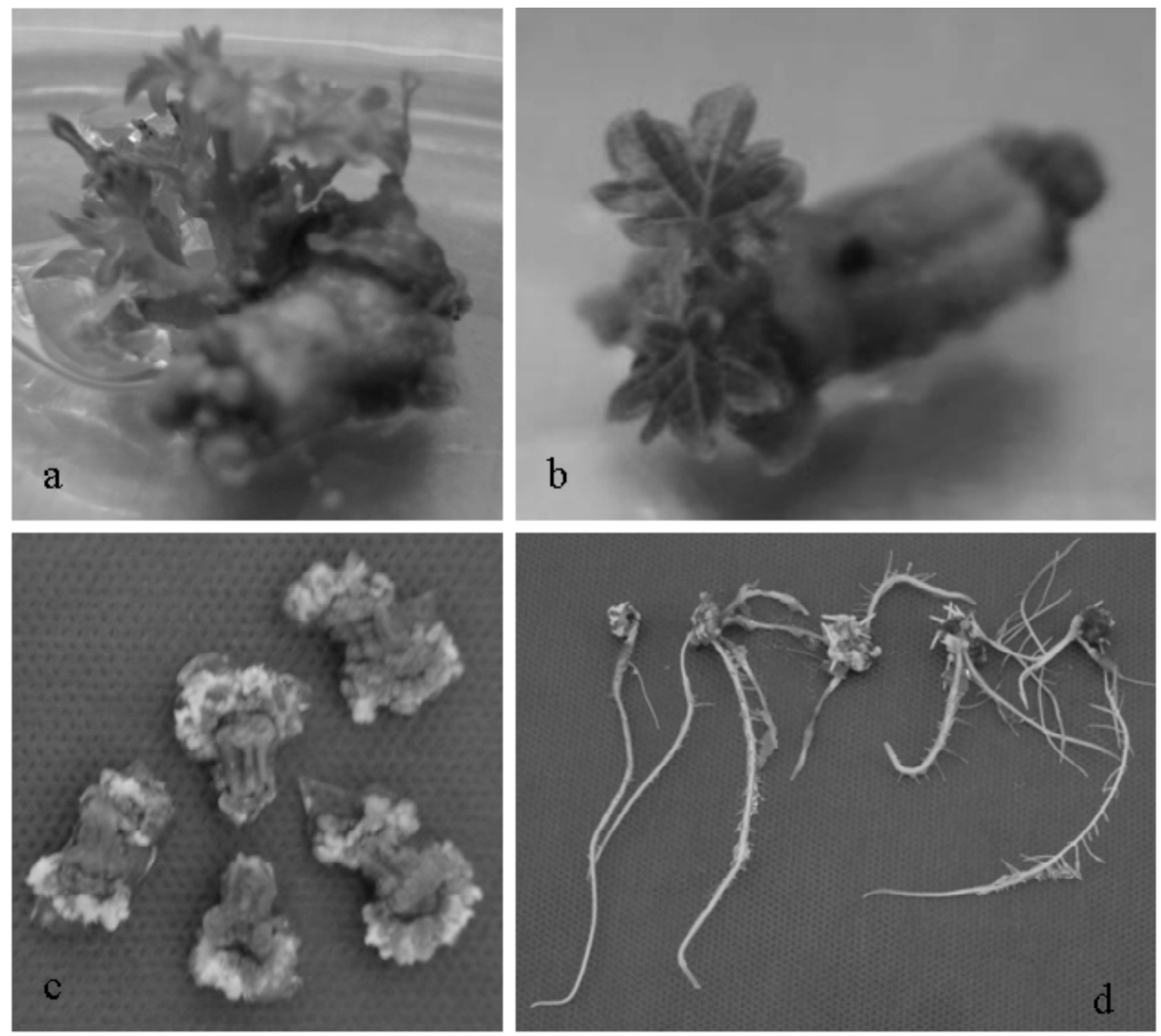

Figura 1 - Organogênese em segmentos internodais de videira cv. Merlot, cultivados em meio MS/2 suplementado com $1 \mu \mathrm{M}$ de ANA. (a, b) Formação de gemas (2,5 $\mu \mathrm{M}$ de TDZ). (c) Formação de calos (2,5 $\mu \mathrm{M}$ de TDZ). (d) Formação de raízes $(2,5 \mu \mathrm{M}$ de BAP). 
de 2,5 a $10 \mu \mathrm{M}$ de BAP apresentaram porcentuais de oxidação variando de 10 a 28,3\% (Biasi et al., 1998).

O tempo de exposição dos explantes de Vitis rotundifolia Michx. em meio de cultivo contendo TDZ é crítico para a subsequente proliferação de brotações, tendo essas se tornando amarronzadas e senescentes após o primeiro subcultivo (Sudarsono \& Goldi, 1991). Resultados semelhantes foram observados no desenvolvimento de pistilos de Citrus limon, cultivados em meio suplementado com TDZ que apresentaram senescência (Sipes \& Einset, 1983). A indução da senescência é decorrente do estímulo que o TDZ exerce na produção de etileno.

Outra consideração que pode ser feita com relação aos altos porcentuais de oxidação nos segmentos foliares é o fato de que subcultivos mais frequentes podem reduzir a incidência de oxidação nos explantes (Jaskani et al., 2008), o que sugere que se os segmentos foliares tivessem sido subcultivados quando fosse observado o início da exudação fenólica, a incidência de oxidação poderia ter sido menor.

A incapacidade dos segmentos foliares de formar gemas pode ter sido causada pela presença da concentração de $1 \mu \mathrm{M}$ de ANA no meio de cultivo. Além disso, a eventual formação de calos, $6,6 \%$ com 2,5 e $10 \mu \mathrm{M}$ de BAP em segmentos foliares e a taxa de $30 \%$ de explantes com calos, na concentração de $2,5 \mu \mathrm{M}$ de TDZ pode ter sido promovida pela adição do ANA nos meios (Tabela 3). Na cultivar Perlette de videira, a presença de $1 \mu \mathrm{M}$ de ANA no meio de cultivo promoveu a formação de calos em segmentos nodais $(40 \%)$, em discos foliares $(80 \%)$ e em ápices caulinares $(10 \%)$, além de também induzir enraizamento nesses explantes (Jaskani et al., 2008).

A capacidade de explantes foliares de produzir brotações pode ser uma característica genética da cultivar. Explantes foliares de diversas cultivares de videira apresentaram capacidade para a formação de brotações adventícias, tais como Cabernet Sauvignon, French Colombard, Thompson seedless e White Riesling em taxas de 47, 67, 60 e 42\% de explantes com brotações, respectivamente, porém outras cultivares como Grenach apresentaram taxas bastante reduzidas, (14\%) (Stamp et al., 1990).

Tipos de explantes normalmente diferem quanto à capacidade de formação de calos. Os internódios da cultivar Merlot de videira apresentaram maior potencial com relação aos segmentos foliares, analogamente em macieira internódios são os melhores explantes utilizados para a

Tabela 3 - Porcentual de enraizamento dos explantes, número de raízes por explante e percentual de explantes com calos em videira cv. Merlot, aos 60 dias de cultivo in vitro.

\begin{tabular}{|c|c|c|c|c|}
\hline \multicolumn{5}{|c|}{ Enraizamento dos explantes (\%) } \\
\hline \multirow[t]{2}{*}{$\mu \mathrm{M}$} & \multicolumn{2}{|c|}{ BAP } & \multicolumn{2}{|c|}{ TDZ } \\
\hline & Seg. foliares & Internódios & Seg. foliares & Internódios \\
\hline 2,5 & $18,3 \mathrm{aB}^{(1)}$ & $80 \mathrm{bA}$ & $0 \mathrm{aC}$ & $0 \mathrm{aC}$ \\
\hline 5,0 & $0 \mathrm{bB}$ & $95 \mathrm{aA}$ & $0 \mathrm{aB}$ & $1,6 \mathrm{aB}$ \\
\hline 10,0 & $0 \mathrm{bA}$ & $1,6 \mathrm{cA}$ & $0 \mathrm{aA}$ & $0 \mathrm{aA}$ \\
\hline \multicolumn{5}{|c|}{ Número de raízes por explante } \\
\hline$\mu \mathrm{M}$ & \multicolumn{2}{|c|}{ BAP } & \multicolumn{2}{|c|}{ TDZ } \\
\hline & Seg. foliares & Internódios & Seg. foliares & Internódios \\
\hline 2,5 & $0,6 \mathrm{aB}$ & $3,2 \mathrm{aA}$ & $0 \mathrm{aC}$ & $0 \mathrm{aC}$ \\
\hline 5,0 & $0 \mathrm{bB}$ & $2,5 \mathrm{bA}$ & $0 \mathrm{aB}$ & $0,1 \mathrm{aB}$ \\
\hline 10,0 & $0 \mathrm{bA}$ & $0 \mathrm{cA}$ & $0 \mathrm{aA}$ & $0 \mathrm{aA}$ \\
\hline \multicolumn{5}{|c|}{ Explantes com calos (\%) } \\
\hline$\mu \mathrm{M}$ & \multicolumn{2}{|r|}{ BAP } & \multicolumn{2}{|c|}{ TDZ } \\
\hline & Seg. foliares & Internódios & Seg. foliares & Internódios \\
\hline 2,5 & $6,6 \mathrm{aC}$ & $56,6 \mathrm{aB}$ & $30 \mathrm{aC}$ & $90 \mathrm{aA}$ \\
\hline 5,0 & $0 \mathrm{aB}$ & $61,6 \mathrm{aA}$ & $0 \mathrm{bB}$ & $66,6 \mathrm{bA}$ \\
\hline 10,0 & $6,6 \mathrm{aA}$ & $0 \mathrm{bA}$ & $0 \mathrm{bA}$ & $10 \mathrm{cA}$ \\
\hline
\end{tabular}

${ }^{(1)}$ Tratamentos seguidos por letras idênticas minúsculas nas colunas e maiúsculas nas linhas não diferem entre si pelo teste de Tukey, ao nível de $5 \%$ de probabilidade de erro. 
obtenção de calos (Morales et al., 1999). Com relação à capacidade de formação de calos das citocininas, resultados semelhantes foram obtidos em segmentos nodais do porta-enxerto de videira 'Jales', em que o BAP induziu à formação de calos, variando entre 32,8 a $100 \%$ nas concentrações de 2,5 a $10 \mu \mathrm{M}$ (Biasi et al., 1998).

A ação do TDZ na formação de calos em espécies lenhosas já foi observada em muitas espécies, e esse regulador é considerado um excelente estimulante para a formação de calos (Huetteman \& Preece, 1993). Em alguns casos, a atividade do TDZ tem sido melhor do que as citocininas derivadas da adenina (Sudarsono \& Goldi, 1991). No entanto, apesar do TDZ apresentar efeito estimulatório na biossíntese do etileno e consequentemente resultar na senescência e oxidação dos explantes, essa citocinina é muito usada em cultura de tecidos pela sua poderosa ação morfogênica, contudo esses efeitos negativos podem ser superados com o uso de substância inibidoras da biossíntese do etileno, tais como nitrato de prata e algumas poliaminas, o que poderá possibilitar o uso de segmentos foliares para a formação de calos, por outro lado, os calos formados em internódios com 2,5 $\mu \mathrm{M}$ de TDZ parecem ser mais promissores para o estabelecimento de protocolos de regeneração in vitro de plantas dessa cultivar.

\section{CONCLUSÕES}

A organogênese da videira cv. Merlot pode ser obtida com segmentos internodais em meio de cultura com $1 \mu \mathrm{M}$ de ANA e 2,5 ou $5 \mu \mathrm{M}$ de TDZ.

\section{REFERÊNCIAS BIBLIOGRÁFICAS}

BAJAJ, Y.P.S. Micropropagation of Grapevine (Vitis vinifera). In: __ Biotechnology in agriculture and forestry 18. New York: Springer-Verlag, 1992. p.371-398.

BIASI, L.A.; PASSOS, I.R.S.; POMMER, C.V. Estabelecimento in vitro de porta-enxertos de videira através de ápices meristemáticos e segmentos nodais. Scientia Agricola, Piracicaba, v.55, n.2, p.196-202, 1998.

BOUQUET, A.; DAVIES, H.P. Culture in vitro d'ovules et d'embryons de vigne (Vitis vinifera L.) appliquée à la sélection de variétés de raisins de table sans pépins. Agronomie, v.9, n.66, p.565-574, 1989.

BROWN, S.C.; COOMBE, B.G. Solute accumulation by grape pericarp cells: II., studies with protoplasts and isolated vacuoles. Biochemie und Physiologie der Pflanzen, Jena, v.179, p.157-171, 1984.

CRUZ, C.D. Programa genes: versão Windows: aplicativo computacional em genética e estatística. Viçosa, MG: UFV, 2001. 648p.

DAS, D.K.; NIRALA, N.K.; REDDY, M.K.; SOPORY, S.K.; UPADHYAYA, K.C. Encapsulated somatic embryos of grape (Vitis vinifera L.): An efficient way for storage and propagation of pathogen-free plant material. Vitis, Paris, v.45, n.5, p.179-184, 2006.

GOUSSARD, P.G. Effects of cytokinins on elongation, proliferation and total mass of shoots derived from shoot apices of grapevine cultured in vitro. Vitis, Paris, v.20, n.3, p.228-234, 1981.

HUETTEMAN, C.A.; PREECE, J.E. Thidiazuron: a potent cytokinin for wood plant tissue culture. Plant Cell, Tissue and Organ Culture, Dordrecht, v.33, n.2, p.105-119, 1993.

INSTITUTO BRASILEIRO DE GEOGRAFIA E ESTATÍSTICA. Disponível em: <http:// iwwW.sidra.ibge.gov.br/ $>$. Acesso em: 5 fev. 2007.

JASKANI, M.J.; ABBAS, H.; SULTANA, R.; KHAN, M.M.; QASIM, M.; KHAN, I.A. Effect of growth hormones on micropropagation of Vitis vinifera L. cv. Perlette.

Pakistan Journal of Botany, v.40, n.1, p.105-109, 2008.

MELLO, L.M.R. Produção e comercialização de uvas e vinhos: panorama 2005. Disponível em: <http:// www.paginarural.com.br/artigos_detalhes.php? id=12 $12 \overline{4}$. Acesso em: 7 fev. 2007.

MEZZETTI, B.; PANDOLFINI, T.; NAVACCHI, O.; LANDI, L. Genetic transformation of Vitis vinifera via organogenesis. BMC Biotechnology, v.2, n.18, p.1-10, 2002.

MORALES, C.F.G.; LOMBARDI, S.R.B.; SOARES, P.F.; FORTES, G.R.L. Efeito do BAP e TDZ na calogênese e organogênese em internódios de macieira cv. Gala RW1.

Revista Brasileira de Agrociência, Pelotas, v.5, n.2, p.174-177, 1999.

MURASHIGE, T.; SKOOG F. Revised medium for rapid growth and bioassays with tobacco tissue culture.

Physiologia Plantarum, Copenhagen, v.15, p.473-497, 1962. 
PASSOS, I.R.S.; SONDAHL, M.R.; RIBEIRO, I.J.A.; TERRA, M.M.; PIRES, E.J.P. Cultura in vitro de meristemas de videira: I., concentrações do hormônio 6BA em meio primário. Bragantia, Campinas, v.44, n.1, p.473-479, 1985.

SIPES, D.L.; EINSET, J.W. Cytokinin stimulation of abscision in lemon pistil explants. Journal of Plant Growth Regulation, Madison, v.2, p.73-80, 1983.

SÔNEGO, O.R.; GARRIDO, L.R.; GRICOLETTI JÚNIOR, A. Principais doenças fúngicas da videira no sul do Brasil. Bento Gonçalves: Embrapa Uva e Vinho, 2005. (Circular Técnica, 56).

STAMP, J.A.; COLBY, S.M.; MEREDITH, C.P. Improved shoot organogenesis from leaves of grape. Journal of
American Horticultural Science, Geneva, v.115, p.1038$1042,1990$.

SUDARSONO, A.; GOLDY, R.G. Growth regulator and axilary bud position effects on in vitro establishment of Vitis rotundifolia. HortScience, Amsterdam, v.26, n.3, p.304-307, 1991.

VIDAL, J.R.; KIKKERT, J.R.; DONZELLI, B.D.; WALLACE, P.G.; REISCH, B.I. Biolistic transformation of grapevine using minimal gene cassette technology. Plant Cell Reports, v.25, n.8, p.807-814, 2006.

ZLENKO, V.A.; KOTIKOV, I.V.; TROSHIN, L.P. Plant regeneration from somatic embryos of interspecific hybrids of grapevine formed in liquid medium. Journal of Horticultural Science and Biotechnology, London, v.80, n.4, p.461-465, 2005. 